\title{
FOSSIL HOLOCENE OSTRACODA FROM THE ITAPEVA LAKE, SOUTHERN BRAZILIAN COASTAL PLAIN
}

\author{
LEONARDO TIMM STEINER CAMPOS D, LUCAS DE OLIVEIRA NUNES (D) \\ Curso de Graduação em Ciências Biológicas, Universidade Federal do Rio Grande do Sul, \\ Câmpus Litoral Norte, Av. Tramandaí, 976, CEP 95625-000, Imbé, RS, Brazil. \\ leotimm.st@gmail.com,nunes.biomar@gmail.com
}

\section{CRISTIANINI TRESCASTRO BERGUE (D}

Departamento Interdisciplinar, Centro de Estudos Costeiros, Limnológicos e Marinhos, Universidade Federal do Rio Grande do Sul, Câmpus Litoral Norte, Av. Tramandaí, 976, CEP 95625-000, Imbé, RS, Brazil.

\author{
ctbergue@gmail.com
}

\begin{abstract}
Holocene ostracods from a core obtained in the Itapeva Lake, Rio Grande do Sul coastal plain, are studied in this paper. Twenty-six species belonging to 22 genera and 13 families were registered in nine samples analyzed, two of them new: Cytherella eros sp. nov. and Loxoconcha itapevensis sp. nov. The taxonomic composition of the assemblages varies along the core, being Cyprideis multidentata Hartmann the most abundant and frequent species (273 specimens), followed by Cytheretta punctata Sanguinetti (56 specimens) and $L$. itapevensis sp. nov. (51 specimens). Variation in richness and diversity observed along the core probably results from sedimentary and hydrological changes during the evolution of the Itapeva Lake. The results obtained in this work reinforce the importance of ostracods in the study of coastal paleoenvironments.
\end{abstract}

Keywords: barrier-lagoon system, biostratinomy, micropaleontology, Quaternary.

RESUMO - Este trabalho apresenta o estudo de ostracodes holocênicos provenientes de um testemunho obtido na Lagoa Itapeva, planície costeira do Rio Grande do Sul. Vinte e seis espécies pertencentes a 22 gêneros e 13 famílias foram registradas em nove amostras analisadas, sendo duas novas: Cytherella eros sp. nov. e Loxoconcha itapevensis sp. nov. A composição taxonômica das associações varia ao longo da seção estudada, onde Cyprideis multidentata Hartmann é a espécie mais abundante e frequente (273 espécimes), seguida por Cytheretta punctata Sanguinetti (56 espécimes) e L. itapevensis sp. nov. (51 espécimes). As variações em riqueza e diversidade observadas ao longo do testemunho resultam, provavelmente, de processos sedimentares e mudanças hidrológicas durante a evolução da Lagoa Itapeva. Os resultados obtidos reforçam a importância dos ostracodes no estudo de paleoambientes costeiros.

Palavras-chave: sistema laguna-barreira, bioestratinomia, micropaleontologia, Quaternário.

\section{INTRODUCTION}

Due to eustatic cycles, a system of lakes and lagoons was formed along the southern Brazilian coast during the Holocene (Villwock \& Tomazelli, 1995). These processes can be analyzed from a biological perspective, using fossils that mark environmental changes. Ostracods are an important source of data for such studies because they are sensitive to environmental changes and have abundant fossil record (Duleba et al., 2005). These microfossils proved to be reliable proxies for Quaternary environmental evolution in coastal regions worldwide (Cabral et al., 2006; Coimbra et al., 2006, 2007; Cronin et al., 2007; Reeves et al., 2007; Hong et al., 2019). This paper presents the first taxonomic study on fossil ostracods from the Itapeva Lake. Moreover, it briefly discusses the influence of coastal dynamics on ostracod assemblage composition.

The Itapeva Lake lies in the northern portion of the Rio Grande do Sul coastal plain. This lagoon is a water body considerably shallow, with a maximum depth of $2.7 \mathrm{~m}$ (Ivanoff et al., 2014). It is the first one of a series of coastal lakes and lagoons that are interconnected through meandering canals to the Tramandaí-Armazém Lagoon, which connects them to the Atlantic Ocean. The Itapeva Lake was formed during the Holocene and is part of the barrier-lagoon system IV (Villwock \& Tomazelli, 1995; Buchmann et al., 2009). With the length of approximately $32 \mathrm{~km}$, is the largest lake of the north coast of the Rio Grande do Sul State (Figure 1). 


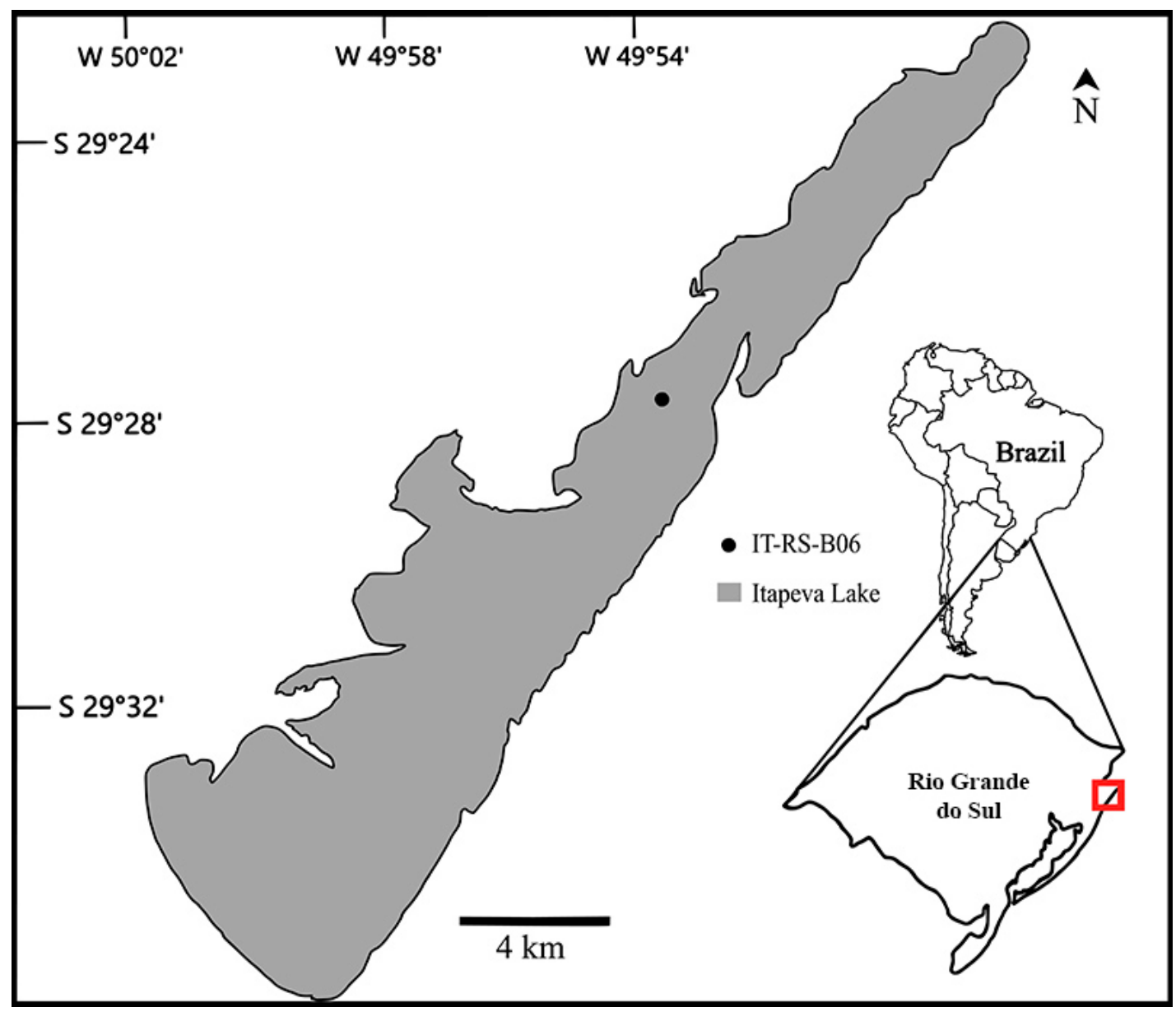

Figure 1. Map of the study area with location of the core IT-RS-B06.

\section{MATERIAL AND METHODS}

The present paper is based on nine samples obtained between 313-170 $\mathrm{cm}$ depth of the vibrocore IT-RS-B06 $\left(29^{\circ} 27^{\prime} \mathrm{S} ; 49^{\circ} 53^{\prime} \mathrm{W}\right)$ (Table 1; Figure 1). This core has been collected for palynological studies and the residual samples made available for use in this work. A stratigraphic profile and additional details of this section, however, are not available. The samples correspond to sections varying from two to four centimeters thick and composed predominantly of fine greyish sand with low organic matter content. The preparation was carried out at Laboratório de Microfósseis Calcários, Universidade Federal do Rio Grande do Sul (UFRGS), through washing on sieves of $0.25 \mathrm{~mm}, 0.18 \mathrm{~mm}$ and $0.063 \mathrm{~mm}$ meshes and oven-dried at $60^{\circ} \mathrm{C}$. All ostracod specimens were picked under stereomicroscope and stored in micropaleontological slides for analysis.

Specimens of each morphotype were selected for SEM (scanning electron microscopy) at Laboratório Central de Microscopia e Microanálise, Pontifícia Universidade Católica do Rio Grande do Sul (PUCRS). The specimens were gold coated in a BAL-TEK SCD-005 equipment. All figured specimens are held at Museu de Paleontologia Irajá Damiani Pinto, Universidade Federal do Rio Grande do Sul, Porto Alegre, Brazil, under the prefix MP-O. The two new species proposed are described in the taxonomic appendix (Appendix 1). For the remaining ones, only remarks are presented whenever necessary because most of these species have been exhaustively studied in previous works. All species registered in this study are in Table 1 (according to their stratigraphic occurrence in the core), and Figures 2-4.

\section{RESULTS}

\section{Ostracod assemblage composition}

The ostracod assemblages of the core IT-RS-B06 are composed predominantly of species previously registered either in coastal or shallow marine (i.e. inner shelf) environments in southern Brazil, Uruguay, and Argentina (see Dias-Brito et al., 1988; Whatley et al., 1997; Coimbra et al., 2006, 2007; Kihn et al., 2016, 2017; Morais \& Coimbra, 2017; Machado et al., 2020; Bernasconi \& Cusminsky, 2020, inter alia). Five morphotypes, however, are left in open nomenclature or compared to previously described species, due to their scarcity or poor preservation: Paracypris sp., Xestoleberis sp., Semixestoleberis? sp., Brasilicythere sp. aff. B. reticulispinosa and Hulingsina sp. Moreover, two new species are herein proposed: Cytherella eros sp. nov. and Loxoconcha itapevensis sp. nov. 
Table 1. Occurrence and abundance of species in the studied samples.

\begin{tabular}{|c|c|c|c|c|c|c|c|c|c|}
\hline Depth $(\mathrm{cm})$ & $\frac{ \pm}{\stackrel{J}{2}}$ & 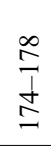 & $\begin{array}{l}\stackrel{2}{1} \\
\stackrel{b}{0}\end{array}$ & $\begin{array}{l}\text { ֶै } \\
\text { 1े } \\
\infty \\
\sim\end{array}$ & $\begin{array}{l}\stackrel{R}{N} \\
\text { iे } \\
\text { d }\end{array}$ & \begin{tabular}{l} 
ते \\
\} $\\
{\text { ते }}$ & $\begin{array}{l}\infty \\
\stackrel{\text { సे }}{+} \\
\stackrel{े}{2}\end{array}$ & $\begin{array}{l}\vec{D} \\
\infty \\
\infty \\
\stackrel{\sim}{2}\end{array}$ & $\begin{array}{l}\frac{m}{\tilde{D}} \\
\stackrel{\rho}{\rho}\end{array}$ \\
\hline Cytherella eros sp. nov. & 6 & 13 & 2 & & 1 & 3 & 1 & 1 & 1 \\
\hline Brasilicythere sp. aff. B. reticulispinosa & 2 & & & & & & & & \\
\hline Loxoconha itapevensis sp. nov. & 6 & 2 & & 4 & 6 & 16 & 1 & 3 & 13 \\
\hline Cyprideis multidentata & 28 & 46 & 34 & 12 & 33 & 39 & 14 & 14 & 53 \\
\hline Cyprideis salebrosa & 1 & & & & & & & & \\
\hline Perissocytheridea krommelbeini & & & & & & & & & 1 \\
\hline Perissocytheridea sanantoniensis & & 2 & 2 & & & & & & \\
\hline Paracypris sp. & & & & & & & & & 1 \\
\hline Cytheretta punctata & 15 & 20 & 7 & 2 & 7 & & 1 & 1 & 3 \\
\hline Oculocytheropteron circumcostatum & 1 & & & & & & & & 1 \\
\hline Cytheretta sp. cf. C. punctata & & & & & & & 1 & & \\
\hline Semicytherura caudata & & & & & & 2 & & & \\
\hline Pellucistoma elongata & & & & & & 1 & & & \\
\hline Xestoleberis sp. & & & & & & 1 & & & \\
\hline Papillosacythere parallela & 1 & 5 & 2 & & & & & & \\
\hline Callistocythere nucleoperiscum & 2 & 2 & & 1 & 1 & 1 & & & \\
\hline Coquimba tenuireticulata & 2 & & & & & & & & \\
\hline Coquimba bertelsae & 1 & 1 & 1 & 1 & & & & & \\
\hline Neocaudites planeforma & 2 & 1 & & & & & & & \\
\hline Orionina similis & & 3 & 1 & 2 & & & & & \\
\hline Quadracythere eichlerae & & & & 1 & & & & & \\
\hline Caudites gnomus & & 2 & & & & & & & \\
\hline Nanocoquimba pulchra & 1 & 2 & & & & & & & \\
\hline Hulingsina sp. & & 1 & & & & & & & \\
\hline Semixestoleberis? sp. & & 1 & & & & & & & \\
\hline Protocytheretta sp. cf. P. multicostata & 2 & 1 & 3 & & & & & & \\
\hline
\end{tabular}
\end{tabular}

Based on the studies above mentioned, a number of species registered in the core IT-RS-B06 are typical shallow marine dwellers, such as Callistocythere nucleoperiscum Whatley et al., 1997, Caudites gnomus Coimbra \& Ornellas, 1987, Coquimba bertelsae Sanguinetti et al., 1991, Coquimba tenuireticulata Kotzian, 1982, Cytheretta punctata Sanguinetti, 1979, Nanocoquimba pulchra Ramos, 1996, Neocaudites planeforma Whatley et al., 1997, Oculocytheropteron circumcostatum Ramos et al., 1999, Orionina similis van den Bold, 1963a, Papillosacythere parallela Whatley et al., 1987, Pellucistoma elongata Whatley et al., 1997, Perissocytheridea sanantoniensis Whatley et al., 1997, Quadracythere eichlerae Carreño et al., 1997, and Semicytherura caudata Ramos et al., 1999. Cytherella eros sp. nov. and Loxoconcha itapevensis sp. nov. are also included in this group. Most of these species are rare in the core IT-RS-B06 and are represented predominantly by adults.

Another group is composed of taxa typical of estuaries and lagoons. Cyprideis multidentata Hartman, 1955, Cyprideis salebrosa van den Bold, 1963b and Perissocytheridea krommelbeini Pinto \& Ornellas, 1970 are common, for instance, in the Tramandaí-Armazém Lagoon (Ornellas, 1974; Würdig, 1988), C. multidentata being the dominant taxon in the core IT-RS-B06. Compared to the group of species previously presented, they have more restrict ecological range, i.e. increasing salinity would allow the thriving of some marine species (e.g. loxoconchids, leptocytherids, cytherurids) in a lagoon. On the other hand, the opposite does not occur, and records of Cyprideis multidentata in marine sediments (e.g. Machado et al., 2005, 2020) are characterized by low abundance and are most probably allochthonous.

Two species registered in this work have remarkably wide geographic distribution. Orionina similis was described in the Upper Miocene-Pliocene Melajo Beds (Springvale Formation), in Trinidad. The broad geographic distribution of this species along Brazilian coast was reported for the first time by Coimbra \& Ornellas (1989), who registered it between Pará and Espírito Santo states. Later, Coimbra et al. (2006) and Morais \& Coimbra (2017) expanded its occurrence 


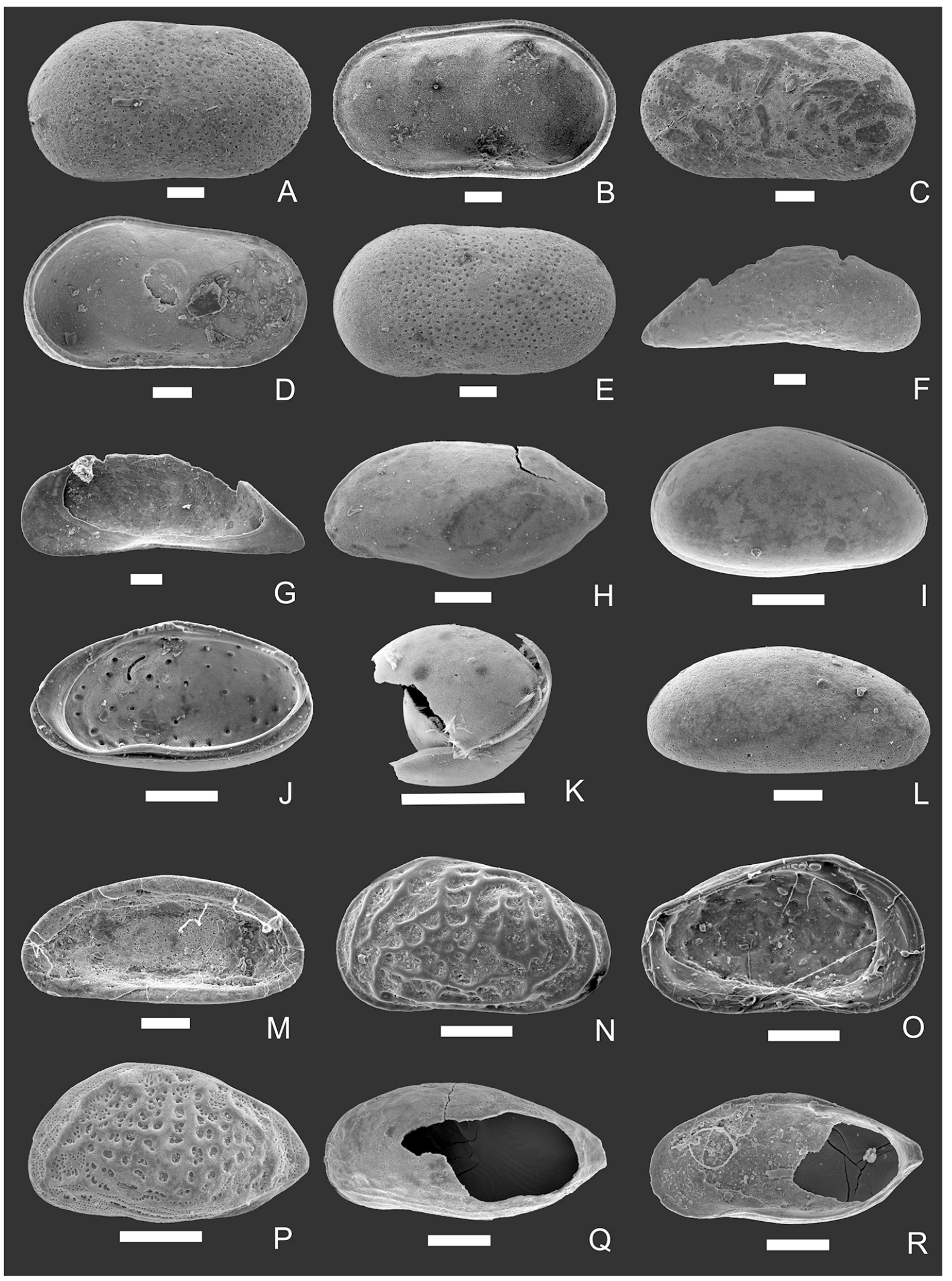

Figure 2. A-E, Cytherella eros sp. nov.; A, female RV (MP-O-3033) holotype; B, same specimen internal view; C, Cytherella eros sp. nov. female LV (MPO-3034), paratype; D, Cytherella eros sp. nov. same specimen internal view; E, Cytherella eros sp. nov. male RV (MP-O-3035), paratype. F-G, Paracypris sp. F, RV (MP-O-3037); G, Same specimen internal view. H, Pellucistoma elongata Whatley et al., 1997, LV (MP-O-3038). I-K, Xestoleberis sp.; I, female C (MP-O-3039); J, RV internal view of the same specimen; K, juvenile specimen (broken) found inside of the carapace MP-O-3039. L-M, Semixestoleberis? sp.; L, RV (MP-O-3040); M, same specimen internal view. N-O, Callistocythere nucleoperiscum Whatley et al., 1997; N, male LV (MP-O-3041); O, same specimen internal view. P, Oculocytheropteron circumcostatum Ramos et al., 1999 LV (MP-O-3042). Q-R, Semicytherura caudata Ramos et al., 1999; Q, LV (MP-O-3045); R, RV internal view (MP-O-3046). Scale bars: A-J, L-R $=100 \mu \mathrm{m} ; \mathbf{K}=50 \mu \mathrm{m}$. 


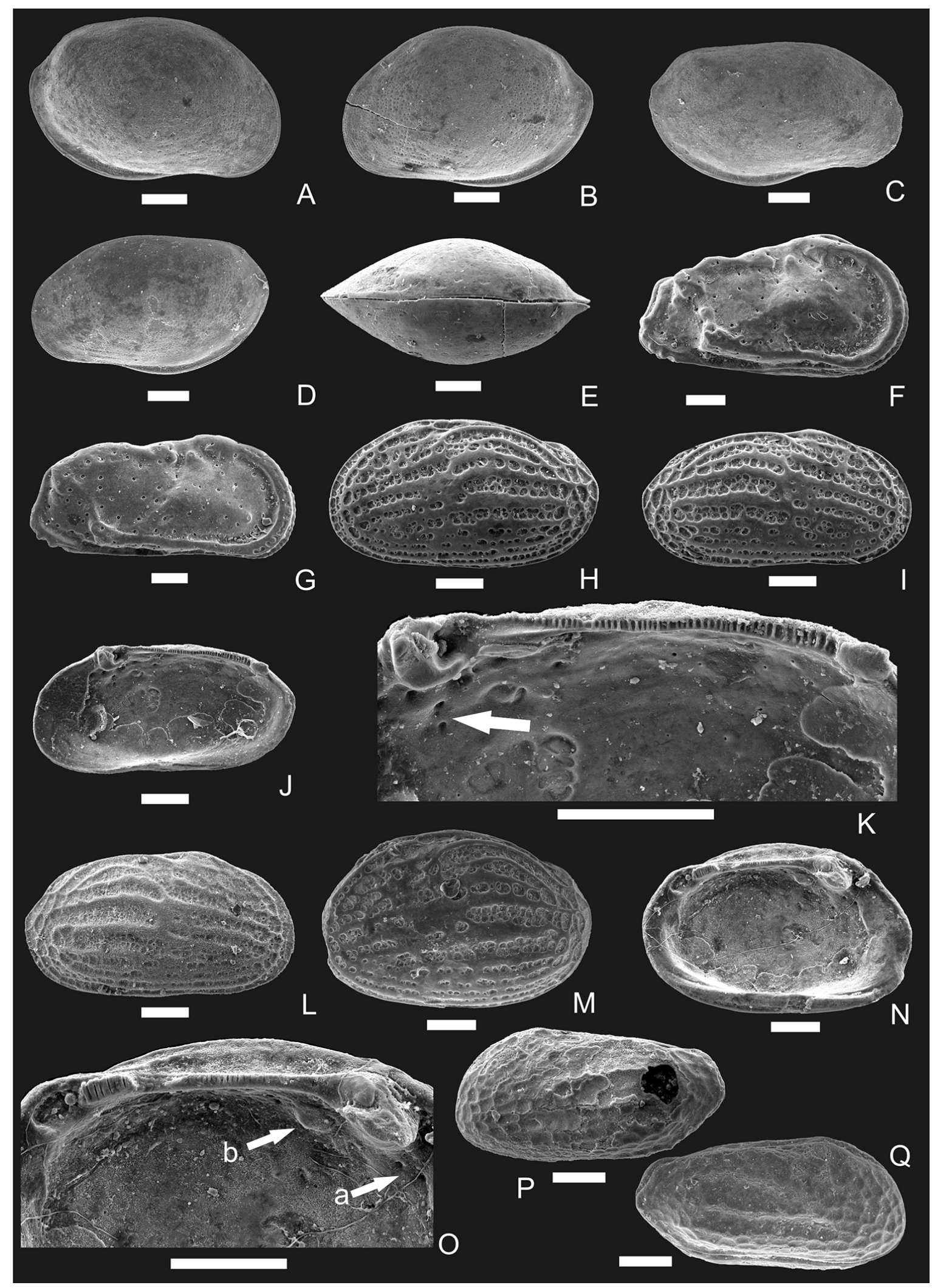

Figure 3. A-E, Loxoconcha itapevensis sp. nov.; A, female RV (MP-O-3044), holotype; B, female LV (MP-O-3045), paratype; C, male RV (MP-O-3047), paratype; D, male LV (MP-O-3046), paratype; E, female C dorsal view (MP-O-3048). F-G, Neocaudites planeforma Whatley et al., 1997; F, female RV (MP-O-3051); G, male RV (MP-O-3050). H-L, Cytheretta punctata Sanguinetti, 1979; H, male LV (MP-O-3052); I, male RV, external view (MP-O-3053); $\mathbf{J}$, male RV internal view (MP-O-3054); K, detail of the hinge of MP-O-3054; L, female RV (MP-O-3055). M-O, Cytheretta sp. cf. C. punctata Sanguinetti, 1979, LV (MP-O-3056); N, same specimen internal view; O, detail of hinge of MP-O-3056. P-Q, Protocytheretta sp. cf. P. multicostata Whatley et al., 1997; $\mathbf{P}$, carapace right view (MP-O-3057); N, same specimen left view. Scale bars $=100 \mu \mathrm{m}$. 


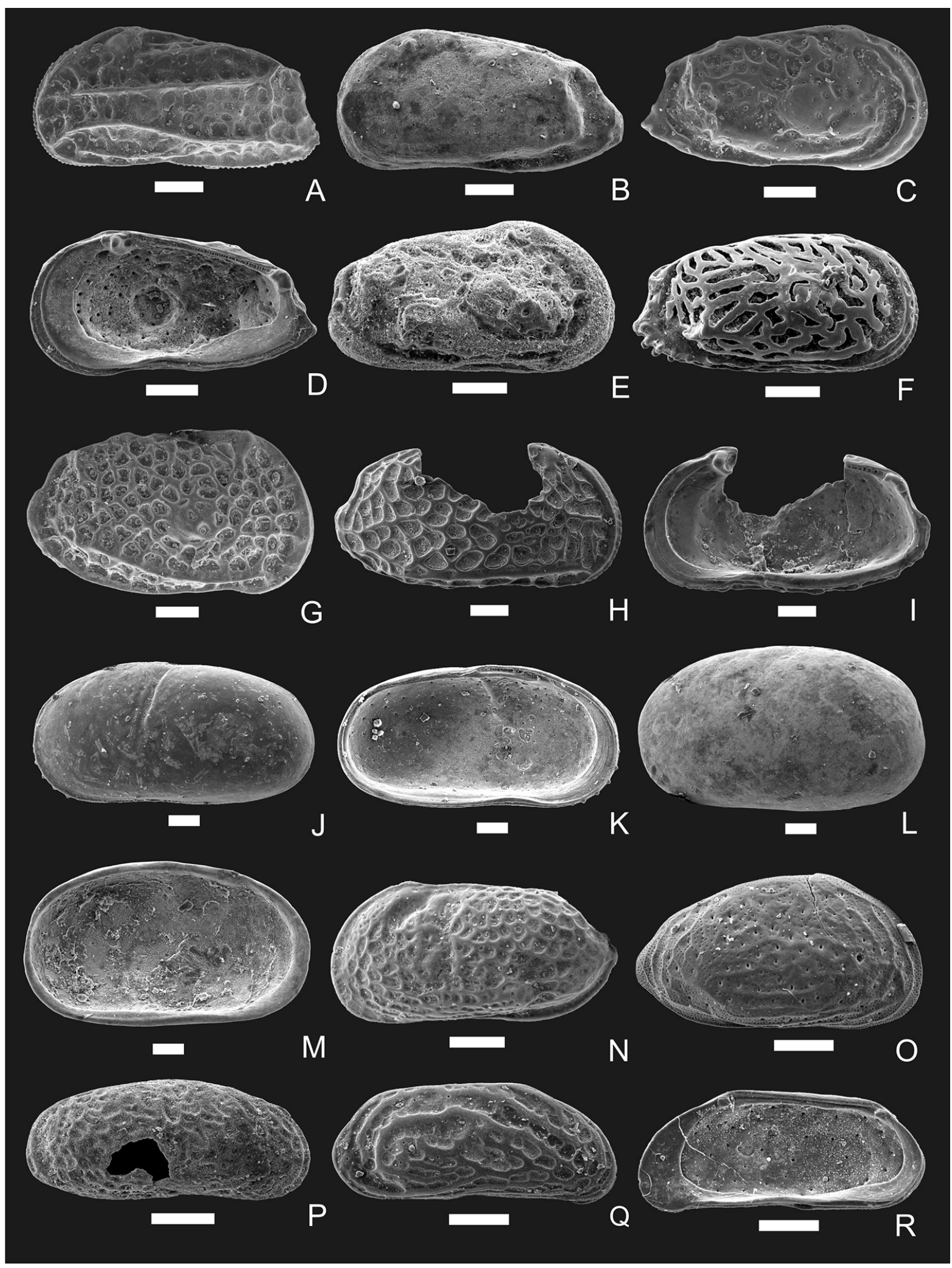

Figure 4. A, Orionina similis van den Bold, 1963a, LV (MP-O-3059). B, Caudites gnomus Coimbra \& Ornellas, 1987, right view (MP-O-3060). C-D, Coquimba tenuireticulata Kotzian, 1982; C, right view (MP-O-3061); D, same specimen internal view. E, Coquimba bertelsae Sanguinetti et al., 1991, C right view (MP-O-3062). F, Nanocoquimba pulchra Ramos, 1996, right view (MP-O-3063). G, Brasilicythere sp. aff. B. reticulispinosa Sanguinetti et al., 1991, RV (MP-O-3064). H-I, Quadracythere eichlerae Carreño et al., 1997; H, broken RV (MP-O-3065); I, same specimen internal view. J-K, Cyprideis multidentata Hartmann, 1955; J, LV (MP-O-3066); K, same specimen internal view. L-M, Cyprideis salebrosa van den Bold, 1963b; L, female LV (MP-O-3067); M, same specimen internal view. N, Perissocytheridea krommelbeini Pinto \& Ornellas, 1970, male LV (MP-O-3068). O, Perissocytheridea sanantoniensis Whatley et al., 1997, RV (MP-O-3069). P, Hulingsina sp. (MP-O-3070). Q-R, Papillosacythere parallela Whatley et al., 1987; Q, RV (MP-O-3071); R, Same specimen internal view. Scale bars $=100 \mu \mathrm{m}$. 
up to the Santa Catarina State. The absence of records in Argentina is evidence that the Rio Grande do Sul State is, probably, the southernmost limit of occurrence of this species. Cyprideis salebrosa was described in the Pliocene Caparo Clay (Talparo Formation), in Trinidad. Differently from $O$. similis, it dispersed further along the South America margin, reaching not only Brazil but Argentina (e.g. Dias-Brito et al., 1988; Whatley et al., 1997; Coimbra et al., 2006; Kihn, 2017; Kinh et al., 2017). Van den Bold (1963b) mentioned that $C$. salebrosa is a rare species due to its ecological preferences. In spite of its broad geographic occurrence, the abundance is relatively low. Additional evidence of this pattern is the disproportionate number of specimens of $C$. multidentata and C. salebrosa in the samples herein studied. It is noteworthy that the same restrictive occurrence has also been observed elsewhere in Brazil by Ornellas \& Würdig (1983) and Würdig (1988) in the Tramandaí-Armazém Lagoon, Rio Grande do Sul State, and by Dias-Brito et al. (1988), in the Sepetiba Bay, Rio de Janeiro State.

The assemblages in the core IT-RS-B06 are composed, therefore, by species with different zoogeographic patterns and ecological preferences. This heterogeneous composition results from environmental changes along the formation of the Itapeva Lake and to biostratinomic processes. Assemblages composed by species with different ecological characteristics are seen not only in deep (e.g. Bergue \& Coimbra, 2007), but also in shallow environments (e.g. Machado et al., 2005, 2020). More recently, Hong et al. (2019) also observed this pattern in coastal assemblages (referred as marginal marine) and highlighted the importance of the ecological characterization of the constituents for paleoecological purposes in Quaternary and Anthropocene deposits.

\section{Lagoonal traps as a model to understand coastal ostracod assemblages}

Lagoons undergo seasonal influence (mostly driven by precipitation and wind) and are inhabited by species adapted to broad range of salinity (i.e. euryhaline taxa). Therefore, some shallow marine species would also live-in lagoons as long as salinity conditions allow it. Notwithstanding, coastal processes also influence the sediment input/output in a lagoon. According to Coimbra et al. (2006), the width and height of the bar can affect the transport of both dead and living ostracod specimens into a lagoon. Another factor influential in sediments exchange is the local hydrodynamics involved in the closure/opening of inlets as well as its depth (Silva et al., 2017). Therefore, in taphonomic terms, a lagoon can act as "ostracod traps" wherein episodic events transport marine specimens which will become allochthonous constituents of the assemblages.

The interval $313-186 \mathrm{~cm}$ of the core IT-RS-B06 registers low species richness (four to eight spp.) being Cyprideis multidentata the most constant and abundant one, totalizing 199 specimens. In this interval occurs also the only register of Perissocytheridea krommelbeini (sample 313-309). Increasing species richness (14 to $18 \mathrm{spp}$.) is seen especially in the interval $178-170 \mathrm{~cm}$, which registers the appearance of Oculocytheropteron circumcostatum, Coquimba tenuireticulata, Nanocoquimba pulchra, Caudites gnomus, and Neocaudites planeforma. Nonetheless, in spite of the increase of marine species, C. multidentata is still the dominant species (28 specimens). The only occurrence of $C$. salebrosa is also in this interval.

Based on palynological analysis, Meyer et al. $(2003,2005)$ observed sporadic marine influence in the Itapeva Lake, and divided the Holocene deposits in ecological zones, ranging from lagunar-estuarine to lacustrine. The ostracods from the core IT-RS-B06, partly corroborate these environmental changes because the core top, which would correspond to the lacustrine environment, was not analyzed in this paper. The ostracod analysis, however, do not distinguish marine species incorporated within the assemblages by sedimentary transport from those that actually thrived in the IT-RS-B06 site during episodes of higher marine influence. The absence of freshwater ostracods reinforces that the studied section does not register any lacustrine phases.

\section{CONCLUSIONS}

This work strengthens the potential of ostracods for paleoecological studies in coastal environments. Coastal ostracod assemblages, at least in some cases, are the result of lagoonal trap deposits, where the proportion and amount of allochthonous elements is influenced both by the depositional system energy and inlet morphodynamics. Some genera, such as Cyprideis, Perissocytheridea, Callistocythere, Loxoconcha and Cytheretta, are ubiquitous in those assemblages in the southeastern coast of America. Slight variation in carapace features observed in Cytheretta punctata and Callistocythere nucleoperiscum are possibly induced by seasonal changes in water salinity (see Carbonel, 1988). The continual co-occurrence of both adults and juveniles of Cyprideis multidentata along the studied section is a supporting evidence that the studied interval of the core IT-RS-B06 represents a lagoon with variable input of marine elements.

\section{ACKNOWLEDGEMENTS}

This paper results of an undergraduate research project of Laboratório de Microfósseis Calcários, developed at Centro de Estudos Costeiros, Limnológicos e Marinhos - Ceclimar. The authors are deeply indebted to J.C. Coimbra who kindly provided the samples and reviewed the manuscript. S.N. Brandão is thanked for bibliographic supply, and M.I.F. Ramos for revision. Our gratitude is also extended to M.C.O. da Costa, who carried out the sample's preparation and part of the picking process.

\section{REFERENCES}

Bengtson, P. 1988. Open nomenclature. Palaeontology, 31:223-227. Bergue, C.T. \& Coimbra, J.C. 2007. Javanella sanfordae, a new Cytheridae (Crustacea: Ostracoda) species with a discussion on 
Revista Brasileira de Paleontologia, 24(2), 2021

the validity of the genus Javanella Kingma. Revista Brasileira de Paleontologia, 10:151-156. doi:10.4072/rbp.2007.3.02

Bernasconi, E. \& Cusminsky, G. 2020.Calcareous microorganisms as indicators of oceanographic conditions in South West Atlantic Ocean. Journal of Marine Systems, 208:103369. doi:10.1016/j. jmarsys.2020.103369

Bertels, A.; Kotzian, S.C.B. \& Madeira-Falcetta, M. 1982. Micropaleontologia (foraminíferos y ostracodos) del cuaternario de Palmares do Sul (Formación Chui), Brasil. Ameghiniana, 19:125-156.

Buchmann, F.S.; Caron, F.; Lopes, R.P.; Ugri, A. \& Lima, L.G. 2009. Panorama geológico da Planície Costeira do Rio Grande do Sul. In: A.M. Ribeiro; S.G. Bauerman \& C.S. Scherer (orgs.) Quaternário do Rio Grande do Sul: integrando conhecimentos, Sociedade Brasileira de Paleontologia, p. 35-56.

Cabral, M.C.; Freitas, M.C.; Andrade, C. \& Cruces, A. 2006. Coastal evolution and Holocene ostracods in Melides lagoon (SW Portugal). Marine Micropaleontology, 60:181-204. doi:10.1016/j.marmicro.2006.04.003

Carbonel, P. 1988. Ostracods and the transition between fresh and saline waters. In: P. De Deckker; P. Colin \& J.-P. Peypouquet (eds.) Ostracoda in the Earth Sciences, Elsevier, p. 157-174.

Carreño, A.L.; Coimbra, J.C. \& Sanguinetti, Y.T. 1997. Bioestratigraphy of late Neogene and Quaternary ostracodes from Pelotas Basin, Southern Brazil. Gaia, 14:33-43.

Coimbra, J.C.; Carreño, A.L.; Geraque, E.A. \& Eichler, B.B. 2007. Ostracodes (Crustacea) from Cananéia-Iguape estuarine/lagoon system and geographical distribuition of mixohaline assemblages in southern and southeastern Brazil. Iheringia, Série Zoologia, 97:273-279. doi:10.1590/S0073-47212007000300010.

Coimbra, J.C.; Costa, K.B. \& Fauth, G. 2006. Palaeoenvironmental significance of allochthonous vs. autochthonous Late Quaternary ostracodes from Imaruí Lagoon and d'Una River, southern Brazil. Revista Brasileira de Paleontologia, 9:295-302. doi:10.4072/rbp.2006.3.04

Coimbra, J.C. \& Ornellas, L.P. 1987. The Subfamily Orionininae Puri, 1973 (Ostracoda; Hemicytheridae) in the Brazilian Continental Shelf, part II. Sistematic of the genus Caudites Coryell \& Fields, 1973. Pesquisas, 19:55-80. doi:10.22456/1807-9806.21682

Coimbra, J.C. \& Ornellas, L.P. 1989. Distribution and ecology of sub-recent Orioninae (Ostracoda) in the Brazilian continental shelf. Revista Brasileira de Geociências, 19:177-186.

Coimbra, J.C.; Sanguinetti, Y.T. \& Bittencourt-Calcagno, V.M. 1995. Taxonomy and distribution patterns of recent species of Callistocythere Ruggieri, 1993 (Ostracoda) from the Brazilian Continental shelf. Revista Española de Micropaleontologia, 27:117-136.

Cronin, T.M.; Vogt, P.R.; Willard, D.A.; Thunell, R.; Halka, J.; Berke, M \& Pohlman, J. 2007. Rapid sea level rise and ice sheet response to 8,200-year climate event. Geophysical Research Letters, 34:L20603. doi:10.1029/2007GL031318

Dias-Brito, D.; Moura, J.A. \& Würdig, N.L. 1988. Relationships between ecological models based on ostracods and foraminifera from Sepetiba Bay (Rio de Janeiro-Brazil). In: T. Hanai; N. Ikeya \& K. Ishizaki (eds.) Evolutionary Biology of Ostracoda, its fundamentals and applications, Elsevier, p. 467-484.

Duleba, W.; Coimbra, J.C.; Petri, S. \& Barbosa, C.F. 2005. Foraminíferos, tecamebas e ostracodes recentes utilizados como bioindicadores em estudos ambientais brasileiros. In: C.R. Souza; K. Suguio; A.M.S. Oliveira \& P.E. Oliveira (eds.) Quaternário do Brasil, Associação Brasileira de Estudos do Quaternário, p. 176-210.
Hartmann, G. 1955. Neue marine Ostracoden der Familie Cypridae und der Subfamilie Cytherideinae der Familie Cytheridae aus Brasilien. Zoologischer Anzeiger, 154:109-127.

Hartmann, G. 1956. Weitere neu marine Ostracoden aus Brasilien. Beitrage zur Neotropischen Fauna, 1:19-62. doi:10.1080/01650525609380609

Hong, Y.; Yasuhara, M.; Iwatani, H. \& Mamo, B. 2019. Baseline for ostracod-based northwestern Pacific and Indo-Pacific shallow-marine paleoenvironmental reconstructions: ecological modeling of species distributions. Biogeosciences, 16:585-604. doi:10.5194/bg-16-585-2019

Ivanoff, M.D.; Toldo Jr., E.E. \& Figueira, R.C.L. 2014. Sedimentação da Lagoa Itapeva, RS, Brasil. Pesquisas em Geociências, 41:3-13. doi:10.22456/1807-9806.78028

Kihn, R.G. 2017. Invasion de Cyprideis salebrosa (Ostracoda, Crustacea) in Bahia Blanca estuary, Buenos Aires, Argentina. Instituto de Ciencia de la Tierra y Ambientales de La Pampa, 12:644-649.

Kihn, R.G.; Martínez, D.E. \& Gómez, E.A. 2017. Associaciones de ostrácodos del intermareal del estuário de Bahía Blanca, Argentina. Revista Brasileira de Paleontologia, 20:91-100. doi:10.4072/rbp.2017.1.07

Kihn, R.G.; Martínez, D.E.; Gómez, E.A. \& Borel, C.M. 2016. Asociaciones de ostrácodos de bentônicos actuales y del Holoceno del Estuario de Bahía Blanca (Buenos Aires, Argentina): interpretaciones paleoambientales. Revista Brasileira de Paleontologia, 19:465-480. doi:10.4072/ rbp.2016.3.11

Liebau, A. 2005. A revised classifiction of the higher taxa of Ostracoda. Hydrobiologia, 538:115-137. doi:10.1007/s10750004-4943-7

Machado, C.P.; Coimbra, J.C. \& Bergue, C.T. 2020. Provinciality of Ostracoda (Crustacea) in the northeastern and eastern Brazilian shelves based on neontological and paleontological analyses. Revista Brasileira de Paleontologia, 23:3-31. doi:10.4072/ rbp.2020.1.01

Machado, C.P.; Coimbra, J.C. \& Carreño, A.L. 2005. The ecological and zoographical significance of the sub-Recent Ostracoda off Cabo Frio, Rio de Janeiro State, Brazil. Marine Micropaleontology, 55:235-253. doi:10.1016/j. marmicro.2005.03.002

Meyer, K.E.B; Reichhart, K.; Ashraf, A.R.; Marques-Toigo, M. \& Mosbrugger, V. 2005. Holocene evolution of Itapeva Lake, Rio Grande do Sul, Brazil: palynomorphs $\mathrm{C}_{\text {org }}$, N, and $\mathrm{S}$ records. Journal of South American Earth Sciences, 19:181-192. doi:10.1016/j.jsames.2005.04.001

Meyer, K.E.B.; Reichhart, K.; Ashraf, A.R.; Marques-Toigo, M.; Souza, P.A. \& Mosbrugger, V. 2003. Evolução ambiental holocênica da Lagoa Itapeva, Planície Costeira do Rio Grande do Sul, Brasil. CONGRESSO DAASSOCIAÇÃO BRASILEIRA DE ESTUDOS DO QUATERNÁRIO, 9, 2003. Resumos Expandidos, Recife.

Morais, L.M.M. \& Coimbra, J.C. 2017. Ostracoda (Crustacea) from the infralittoral of Santa Catarina State, southern Brazil. Marine Biodiversity, 49:69-82. doi:10.1007/s12526-017-0755-7

Ornellas, L.P.D. 1974. Minicythere heinii Ornellas, gen. et sp. nov., from southern Brazil, and a characteristic ostracode association of brackishwater environment. Anais de Academia Brasileira de Ciências, 46:469-496.

Ornellas, L.P. \& Würdig, N.L. 1983. Cyprideis salebrosa hartmanni Ramirez, 1967, a new subspecies from Brazil and Argentina. Pesquisas, 15:94-112. doi:10.22456/1807-9806.21725 
Pinto, I.D. \& Ornellas, L.P. 1970. A new brackish water ostracode Perissocytheriidea krommelbeini Pinto \& Ornellas, sp. nov., from Southern Brazil. Escola de Geologia da UFRGS, 20:1-19.

Ramos, M.I.F. 1996. Taxonomy and zoogeography of the ostracod genera Nanocoquimba and Cornucoquimba Ohmert, 1968 from recent sediments on the Brazilian Continental Shelf. Revista Española de Micropaleontologia, 28:105-128.

Ramos, M.I.F.; Coimbra, J.C.; Bergue, C.T. \& Whatley, R.C. 2012. Recent ostracods (family Trachyleberididae) from the southern Brazilian continental shelf. Ameghiniana, 19:3-16. doi:10.1007/ s12526-017-0755-7

Ramos, M.I.F.; Coimbra, J.C.; Whatley, R.C. \& Moguilevsky, A. 1999. Taxonomy and ecology of the family Cytheruridae (Ostracoda) in Recent sediments from the northern Rio de Janeiro coast, Brazil. Journal of Micropaleontology, 18:1-16. doi:10.1144/jm.18.1.1

Reeves, J.; Chivas, A.R.; Garcia, A. \& De Deckker, P. 2007. Palaeoenvironmental change in the Gulf of Carpentaria (Australia) since the last interglacial. Palaeogeography, Palaeoclimatology, Palaeoecology, 246:163-187. doi:10.1016/j. palaeo.2006.09.012

Rossi de Garcia, E. 1966. Contribución al conocimiento de los ostracodos cenozoicos de la Argentina: 1. Formacion Entre Rios de Victoria, Provincia de Entre Rios. Ameghiniana, 21:194-208.

Sanguinetti, Y.T. 1979. Miocene ostracodes of the Pelotas Basin, State of Rio Grande do Sul, Brasil. Pesquisas, 12:119-187. doi:10.22456/1807-9806.21763
Sanguinetti, Y.T.; Ornellas, L.P. \& Coimbra, J.C. 1991. Post Miocene Ostracodes from Pelotas Basin, Southern Brazil. Taxonomy Part I. Pesquisas, 18:138-155. doi:10.22456/1807-9806.21306

Silva, A.F.; Toldo Jr., E.E. \& Weschenfelder, J. 2017. Morfodinâmica da desembocadura da Lagoa de Tramandaí. Pesquisas em Geociências, 44:155-166.

van den Bold, W.A. 1963a. Upper Miocene and Pliocene Ostracoda of Trinidad. Micropaleontology, 9:361-424.

van den Bold, W.A. 1963b. The ostracode genus Orionina and its species. Journal of Paleontology, 37:33-50.

Villwock, J.A. \& Tomazelli, L.J. 1995. Geologia costeira do Rio Grande do Sul. Notas Técnicas, 8:1-45.

Whatley, R.C.; Chadwick, J.; Coxill, D. \& Toy, N. 1987. New genera and species of cytheracean Ostracoda from the S.W. Atlantic. Journal of Micropalaeontology, 6:1-12. doi:10.1144/jm.6.2.1

Whatley, R.C.; Moguilevsky, A.; Toy, N.; Chadwick, J. \& Ramos, M.I.F. 1997. Ostracoda from the south west Atlantic. Part II. The littoral fauna from between Tierra del Fuego and the Rio de La Plata. Revista Española de Micropaleontologia, 29:5-83.

Würdig, N.L. 1988. Distribuição espacial e temporal da comunidade de ostracodes nas lagoas Tramandaí e Armazém, Rio Grande do Sul, Brasil. Acta Limnologica Brasiliensis, 2:701-722.

Received in 31 August, 2020; accepted in 04 March, 2021. 
Appendix 1. Taxonomy.

The suprageneric taxonomy herein used follows mainly Liebau (2005), while open nomenclature signs follow Bengtson (1988). Morphological abbreviations: H, height; $\mathbf{L}$, length; W, width; $\mathbf{C}$, carapace; $\mathbf{R V}$, right valve; $\mathbf{L V}$, left valve; AMS, adductor muscle scars.

Subclass OSTRACODA Latreille, 1806

Order PLATYCOPIDA Sars, 1866

Superfamily CYTHERELLOIDEA Sars, 1866

Family CYTHERELLIDAE Sars, 1866

Cytherella Jones, 1849

Cytherella eros Nunes \& Campos sp. nov. urn:Isid:zoobank.org:act:45D9D3DE-30BF47F4-8840-76BDB0CE075C

(Figures 2A-E)

Etymology. $L$. in allusion to its similarity to the underground growing fruit of Arachis hypogaea (peanut).

Holotype. MP-O-3033, female RV, $\mathrm{L}=0.77 \mathrm{~mm}, \mathrm{H}=0.45$ mm (IT-RS-BO06/53 178-174 cm).

Paratypes. MP-O-3034, female LV, $\mathrm{L}=0.73 \mathrm{~mm}, \mathrm{H}=0.40$ mm (IT-RS-BO06/53 178-174 cm); MP-O-3035, male RV, $\mathrm{L}=0.76 \mathrm{~mm}, \mathrm{H}=0.42 \mathrm{~mm}$ (IT-RS-BO06/53 178-174 cm); MP-O-3036, female LV, $\mathrm{L}=0.74 \mathrm{~mm}, \mathrm{H}=0.42 \mathrm{~mm}$ (IT-RSBO06/53 178-174 cm).

Type-locality and horizon. Itapeva Lake, core IT-RS-B06

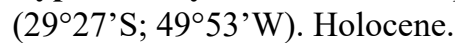

Material. Twenty-eight specimens, adults, and juveniles.

Diagnosis. Carapace subrectangular, slightly constricted in the middle, higher and inflated at posterior region. RV overlapping LV around all margins. Surface densely punctuated, except in the region corresponding to the AMS. Description. Carapace subrectangular elongated in lateral view, higher and wider at the posterior third. RV overlapping LV around all margins. Maximum length at the middle, and maximum width at the posterior third of carapace. Dorsal margin slightly constricted in the middle; ventral margin sinuous with concavity in the oral region. Anterior margin symmetrically rounded; posterior margin asymmetrically rounded, somewhat obliquely rounded. Posterior third of carapace slightly inflated. Surface densely punctuated, except in the area corresponding to the AMS. Contact groove well developed along the dorsal, ventral and posterior margins in the RV. AMS not seen. Sexual dimorphism conspicuous: females wider and slightly higher in the posterior.

Geographic and stratigraphic distribution. Known only for the type-locality.

Remarks. Cytherella eros sp. nov. belongs to a group of undescribed Cytherella species characterized by punctuated surface. It is very similar to Cytherella sp. of Coimbra et al. (2006) but is less punctuated and differs in the sinuosity of the ventral margin. From Cytherella sp. 1 and Cytherella sp. 2 of Machado et al. (2005), differs mostly in the outline of the posterior margin, and in the pattern of punctuation. Cytherella sp. 4 of Machado et al. (2020) has the posterior third of carapace lower and the ventral margin straight, and puncta larger and deeper. At last, Cytherella sp. of Bertels et al. (1982), although similar to Cytherella eros sp. nov., is distinguished in having the posterior portion of carapace lower.

Order PODOCOPIDA Sars, 1866 Superfamily CYTHEROIDEA Baird, 1850 Family LOXOCONCHIDAE Sars, 1925

\section{Loxoconcha Sars, 1866}

Loxoconcha itapevensis sp. nov. urn:lsid:zoobank.org:act:6A7C77C7-F3DB4C13-84C1-B9B3129FB55E

(Figures 3A-E)

?Loxoconcha sp. Bertels, Kotzian \& Madeira-Falcetta, p. 150, pl. 8, figs. 1a-b.

Etymology. In allusion to the type-locality, the Itapeva Lake. Holotype. MP-O-3044, female RV, $\mathrm{L}=0.59 \mathrm{~mm}, \mathrm{H}=0.40$ mm (IT-RS-BO06/82 294-290 cm).

Paratypes. MP-O-3045, female LV, $\mathrm{L}=0.59 \mathrm{~mm}, \mathrm{H}=0.41$ $\mathrm{mm}$; MP-O-3046, male LV, L=0.61 mm, $\mathrm{H}=0.36 \mathrm{~mm}$; MPO-3047 male RV, $\mathrm{L}=0.61 \mathrm{~mm}, \mathrm{H}=0.36 \mathrm{~mm}$; MP-O-3048 female $\mathrm{C}, \mathrm{L}=0.59 \mathrm{~mm}, \mathrm{H}=0.41 \mathrm{~mm}, \mathrm{~W}=0.30 \mathrm{~mm}$; MP-O3049 male $\mathrm{C}, \mathrm{L}=0.61 \mathrm{~mm}, \mathrm{H}=0.35 \mathrm{~mm}, \mathrm{~W}=0.27 \mathrm{~mm}$ (all from the sample IT-RS-BO06/82 $294-290 \mathrm{~cm}$ ).

Type-locality and horizon. Itapeva Lake, core IT-RS-B06 $\left(29^{\circ} 27^{\prime} \mathrm{S} ; 4^{\circ} 53^{\prime} \mathrm{W}\right)$. Holocene.

Material. 51 specimens, juveniles, and adults.

Diagnosis. A Loxoconcha species with finely punctuated surface and with very faint anteroventral reticulation. Posterodorsal region of carapace marked by subtle tubercle. Eye tubercle and caudal process poorly developed.

Description. Carapace subrhomboidal in lateral view; subelliptical outline in dorsal view, subtly compressed anteriorly. Maximum length and maximum width at the middle. Dorsal margin convex in females, and subrectilinear and slightly sinuous in males. Ventral margin very sinuous with strong convexity at posterior half. Anterior margin infracurvate; posterior margin with caudal process poorly developed in females, and almost absent in the males. Eye tubercle poorly developed. Carapace finely punctuated over all surface, and with faint anteroventral reticulation. Puncta are roughly disposed concentrically, larger in the middle of carapace and gradually smaller towards the anterior and posterior margins. Posterodorsal area marked with poorly developed tubercle. Internal features typical of the genus. Sexual dimorphism very conspicuous: males longer than females. For other sexual differences see the description above.

Geographic and stratigraphic distribution. Known only for the type-locality. 
Remarks. Loxoconcha itapevensis sp. nov. differs from Loxoconcha bullata Hartmann, 1956 described in the São Paulo State (Brazil) in having dorsal margin more convex, the caudal process less developed, and posterodorsal tubercle less pronounced and more obtuse. Loxoconcha bullata of Whatley et al. (1997) differs in having the dorsal margin far more convex and in the absence of caudal process. The latter is in fact more similar to Loxoconcha sp. of Machado et al. (2020) than to L. bullata. Based both on size and absence of duplicature, Loxoconcha sp. of Bertels et al. (1982) is possibly an A-1 of Loxoconcha itapevensis sp. nov.

Taxonomic remarks on other ostracod species registered Pellucistoma elongata Whatley et al., 1997 (MP-O-3038; Figure 2H)

The specimens of Pellucistoma elongata illustrated by Kihn et al. (2016) in the Bahia Blanca Estuary (Argentina) have some differences in the outline compared to the specimen herein illustrated. These differences result probably from positioning or ontogeny (see figs. 4b-c in Kihn et al., 2016). Kihn et al. (2016) referred the publication of this species to 1998 instead of 1997.

Callistocythere nucleoperiscum Whatley et al., 1997 (MPO-3041; Figures 2N-O)

Callistocythere is a diverse genus in inner shallow marine and coastal waters along eastern South America (Coimbra et al., 1995), whose similarity of some species causes taxonomic problems. According to Machado et al. (2020) Callistocythere nucleoperiscum has been referred erroneously in some works as Callistocythere litoralensis Rossi de Garcia, 1966 which differs in the outline and ribs pattern. Specimens of Callistocythere nucleoperiscum registered in several localities along Brazilian shelf present some degree of variation on ribs thickness [compare, p. ex., the specimen illustrated by Bertels et al. (1982) and Morais \& Coimbra (2017)].

Oculocytheropteron circumcostatum Ramos et al., 1999 (MP$\mathrm{O}-3042$; Figure 2P)

The specimen herein illustrated is slightly different from the holotype which possibly results either from intraspecific variation or ontogeny.

Semicytherura caudata Ramos et al., 1999 (MP-O-3043; Figures 2Q-R)

In spite of poor preservation, the outline and some morphological surface details allowed identification at species level.

Cytheretta punctata Sanguinetti, 1979 (MP-O-3052/55; Figures $3 \mathrm{H}-\mathrm{L}$ )

Cytheretta punctata has several registers along southwestern Atlantic neritic and coastal regions, some of them in affinitive status. Ramos et al. (2012) in their study on trachyleberidids from the southern Brazilian margin registered specimens of $C$. punctata smaller and with delicate reticulation, concluding that those specimens would belong to a species affinitive to Cytheretta punctata. In our opinion, however, carapace size and morphology might occur in species with such a long stratigraphic range. We assume, therefore, that both ribs and reticulation thickness might vary in some species, possibly induced by environmental parameters (see "Remarks" on Callistocythere nucleoperiscum).

Cytheretta sp. cf. C. punctata Sanguinetti, 1979 (MP-O-3056, Figures $3 \mathrm{M}-\mathrm{O}$ )

This species differs from Cytheretta punctata in having less angulose posterior margin. Notwithstanding, the reticulation pattern is basically the same, which could be considered as intraspecific variation if some degree of variability is assumed (see "Remarks" on C. punctata). The data herein obtained do not bring solution to this taxonomic issue, however, some internal morphological details observed in the specimen MPO-3054 (Figures 3J-K) might be useful for future analyses. The position of some normal porecanals in the area adjacent to the anterior hinge element is different from the specimen MP-O-3056 (Figure 3Oa). Moreover, the latter seems to have a muscle-anchorage structure in this same area (Figure 3Ob) which, unfortunately, is partially obscured by detritus.

Protocytheretta sp. cf. P. multicostata Whatley et al., 1997 (MP-O-3057; Figure 3P-Q)

The specimen herein figured is slightly different from the holotype. Such differences, however, might be attributed to preservation or ontogeny.

Brasilicythere sp. aff. B. reticulispinosa Sanguinetti et al., 1991 (MP-O-3064; Figure 4G)

We sustain this is a new species of Brasilicythere affinitive to $B$. reticulispinosa, but with differences in the outline of the anterior margin, the anteroventral region more sinuose and shorter radial ribs at the anterior region. The scarcity of specimens did not allow the description.

Hulingsina sp. (MP-O-3070; Figure 4P)

This specimen is possibly conspecific with Hulingsina? sp. of Whatley et al. (1997) registered in Playa Grande, Buenos Aires Province (Argentina). It is also very similar to the specimen identified as Minicythere argentinensis by Kihn et al. (2017) in Bahía Blanca (Argentina) mainly in the anterodorsal sulcus, the reticulation pattern around the AMS area, and the depressed area adjacent to the posterior margin. The single broken specimen obtained in this work precludes more detailed comparison. Notwithstanding, the carapace morphology of this species is somewhat different from the type-species of Minicythere (i.e. Minicythere heinii Ornellas, 1974), but closer to Huligsina instead. 